\title{
PENGARUH KEPEMIMPINAN, MOTIVASI, DAN DISIPLIN KERJA TERHADAP KINERJA KARYAWAN PADA PT. PP LONDON SUMATERA, TBK, BATU LOKONG, GALANG, BG. POM KABUPATEN DELISERDANG, SUMATERA UTARA
}

\author{
Michael Stefen Nainggolan ${ }^{1)}$, Hendry ${ }^{2)}$ \\ 1) Fakultas Ekonomi, Universitas Prima Indonesia \\ ${ }^{1)}$ Email Correspondence: olo.nainggol123@gmail.com
}

\begin{abstract}
Abstrak
Penelitian ini dilakukan dengan objek dari PT. PP London Sumatera, Tbk, penelitian dilakukan karena ada kecenderungan penurunan kinerja yang dialami perusahaan. Kinerja karyawan adalah hasil kerja dari karyawan di dalam menjalankan pekerjaan yang menjadi beban tanggungjawab karyawan. Penurunan kinerja diduga karena adanya masalah kepemimpinan, motivasi dan disiplin kerja. Kepemimpinan merupakan kemampuan seorang pemimpin dalam menggerakan dan mempengaruhi karyawan. Pada permasalahan kepemimpinan, dari hasil wawancara dengan beberapa karyawan didapati adanya indikasi lemahnya gaya kepemimpinan di PT. PP. London Sumatera,Tbk. Motivasi adalah sebagai pemberi daya gerak yang menciptakan kegairahan kerja seseorangagar mereka mau bekerja sama, bekerja efektif dan terintegrasi dengan segala daya upaya untuk mencapai kepuasan.Pada faktor motivasi, dapat dijelaskan bahwa tinggi atau rendahnya karyawan dalam bekerja sangat dipengaruhi oleh besar atau kecilnya bonus atau tunjangan yang diterima. Disiplin adalah ketaatan karyawan kepada norma-norma dan peraturan yang ada di perusahaan. Penerapan disiplin sangat dibutuhkan dalam mengatur karyawan di perusahaan. Kepemimpinan yang ada kurang tegas terhadap karyawan yang melanggar peraturan yang ada yaitu tentang masalah kedisiplinan kehadiran dalam hal ini tentang izin.Teori yang digunakan dalam penelitian ini merupakan teori dari kepemimpinan, motivasi, disiplin kerja dan kinerja. Pengunaan metode analisis yang akan digunakan meliputi analisis berganda, koefisien determinasi, uji f (Uji-F) $(13,944>2,69)$ dengan nilai dan secara parsial (uji-t) $(2,542>1,983),(3,395>1.983)$ dan $(2,829>1,983)$. Hasil penelitian menunjukkan bahwa kepemimpinan, motivasi dan disiplin kerja simultan dan parsial berpengaruh positif signifikan terhadap kinerja karyawan dengan nilai koefisien determinasi sebesar 27,2\%.
\end{abstract}

Kata kunci : Kepemimpinan, Motivasi, Disiplin Kerja dan Kinerja Karyawan 


\section{PENDAHULUAN}

PT. PP London Sumatera Indonesia Tbk adalah perusahaan perkebunan yang berdiri pada tahun 1906. Perusahaan memiliki model manajemen perkebunan yang terukur dengan teknologi dan komitmen yang tinggi dalam membangun sumber daya manusia. Kemampuan sumber daya manusia di perusahaan cukup kompetitif sampai saat ini dalam meningkatkan produksi perusahaan. Sampai tahun 2018, total tenaga kerja PT.PP London Sumatera Indonesia, Tbk, Batu Lokong, Galang, BG. Pom, Sumatera Utara mencapai 142 karyawan.

Kinerja karyawan adalah bagian dari hasil kerja karyawan yang menjadi beban tanggung jawab karyawan dalam menjalankan pekerjaan.

Dari hasil pengamatan data dan wawancara karyawan, penurunan kinerja karyawan yang terjadi dapat diketahui bahwa selama kurun waktu 5 tahun persentase peningkatan jumlah produksi pada PT. PP. London Sumatera,Tbk hanya mengalami peningkatan yang sedikit, yaitu pada tahun 2017 dan 2018 hanya naik 0,06 persen. Maka hal tersebut dapat dijelaskan bahwa kinerja karyawan belum sepenuhnya maksimal dan hal itu juga dapat dilihat target kerja selama 5 tahun terakhir selalu diturunkan.

Kepemimpinan merupakan kemampuan seorang pemimpin dalam menggerakan dan mempengaruhi karyawan. Pada permasalahan kepemimpinan, dari hasil wawancara dengan beberapa karyawan didapati adanya indikasi lemahnya gaya kepemimpinan di PT. PP. London Sumatera, Tbk. Kepemimpinan paternalistik, dimana pemimpin selalu melindungi bawahannya dan memiliki sifat dominan dalam mengambil keputusan secara sendiri tanpa ada dengar pendapat dari karyawan sehingga dan menyebabkan semua keputusan diambil secara sepihak. Hal ini juga menyebabkan karyawan tidak diberikan kesempatan dalam menyampaikan pendapat dan menyebabkan karyawan tidak kreatif dalam menyampaikan ide dan gagasan yang mereka miliki.

Motivasi adalah pemberian semangat kerja kepada seseorang agar mau bekerjasama, bekerja dengan efektif sehingga mampu untuk mencapai kinerja yang baik bagi perusahaan. Pada faktor motivasi, dapat dijelaskan bahwa tinggi atau rendahnya karyawan dalam bekerja sangat dipengaruhi oleh besar atau kecilnya bonus atau tunjangan yang diterima. Berdasarkan tabel 3 diatas, bahwa rata-rata bonus yang diterima karyawan dari tahun ke tahun kenaikannya hanya sedikit bahkan di tahun terakhir yaitu tahun 2018, bonus yang diterima karyawan mengalami penurunan dan hal ini mengakibatkan adanya penurunan motivasi kerja karyawan

Disiplin adalah ketaatan karyawan kepada norma-norma dan peraturan yang ada di perusahaan. Penerapan disiplin sangat dibutuhkan dalam mengatur karyawan di perusahaan. Pada faktor disiplin, pada pengamatan data selama 4 tahun terakhir yaitu dari 2015-2018. Dimana pada tahun 2016 ada sebanyak karyawan yang izin yaitu 103 orang dan 2018 ada sebanyak 130 orang. Maka hal tersebut sangat berdampak pada hasil kerja yang ada. Artinya dengan banyaknya karyawan yang izin, menggambarkan bahwa kepemimpinan yang ada kurang tegas terhadap karyawan yang melanggar peraturan yang ada yaitu tentang masalah kedisiplinan kehadiran dalam hal ini tentang izin. 


\section{TINJAUAN PUSTAKA}

\section{Teori Pengaruh Kepemimpinan Terhadap Kinerja}

Menurut Noor (2013:168), dengan adanya kepemimpinan yang bijaksana akan memberikan solusi atas kendala yang dihadapi oleh karyawan dalam bekerja dan akan meningkatkan loyalitas kerja karyawan untuk bekerja lebih giat dan terus memberikan ide-ide yang baru.

Menurut Bangun (2012:336), melalui sistem kepemimpinan yang tepat dapat mengangkat perusahaan yang sedang kolaps atau menunggu waktu untuk berhenti beroperasi menjadi pulih kembali dan meningkatkan kinerjanya

Menurut Sutrisno (2012:233), implikasi teori kepemimpinan terhadap karyawan perusahaan maksudnya adalah sejauh mana pemimpin perusahaan mampu mentransformasi pendekatan teori-teori kepemimpinan sebagau pedoman dalam melakukan tugasnya. Sehingga pemimpin perusahaan memiliki kemampuan mempengaruhi dan memberikan motivasi kepada karyawannya yang berdampak pada peningkatan kinerja.

Dari teori pengaruh para ahli, dapat diberikan kesimpulan bahwa kepemimpinan menjadi hal yang penting dalam rangka penyelesaian masalah dan memberikan semangat kerja kepada karyawan yang bekerja.

\section{Teori Pengaruh Motivasi Terhadap Kinerja}

Menurut Wibowo (2014:321), dengan adanya semangat kerja dari diri pekerja, maka akan meningkatkan hasil kerja yang mereka
NIAGAWAN Vol 9 No 1 Maret 2020

miliki. Dengan peningkatan kinerja maka akan meningkatkan hasil kinerja perusahaan keseluruhan.

Menurut Priansa (2016:199), berkaitan dengan motivasi kerja, maka pemberdayaan menjadi isu yang sangat berkaitan. Karena pemberdayaan akan mampu memberikan stimulus bagi pegawai agar termotivasi untuk bekerja. Pegawai yang diberdayakan dengan baik akan mampu meningkatkan kinerja dengan optimal, jika didukung dengan kompensasi yang memadai.

Menurut Hartatik (2014 : 185), disiplin menjadi hal yang mutlak dan harus dilaksanakan dalam organisasi, tanpa adanya dukungan dari karyawan yang memiliki disiplin yang baik, perusahaan akan sulit dalam mencapai target kerja yang diharapkan. Dapat dikatakan bahwa kedisiplinan merupakan kunci dari kemampuan organisasi dalam mencapai target dan tujuan yang ditetapkan.

Dari teori pengaruh para ahli, dapat diberikan kesimpulan bahwa disiplin kerja menjadi sebuah hal yang harus dimiliki oleh karyawan untuk mendukung keberhasilan dan peningkatan kinerja yang lebih baik di perusahaan.

\section{Teori Pengaruh Disiplin Kerja Terhadap Kinerja}

Menurut Sinambela (2016 : 237), disiplin kerja memiliki kaitan erat dengan variabel kinerja. Semakin disiplin seorang karyawan dalam bekerja, maka akan semakin meningkat dan baik juga kinerja karyawan tersebut. Banyak hal lain yang juga berkaitan dengan kinerja, namun hal utama yaitu disiplin kerja. 
Menurut Darmawan (2013:41), pelaksanaan disiplin yang efektif akan merubah perilaku karyawan dan hal ini penting secara langsung untuk meningkatkan kinerja.

Menurut Hartatik (2014 : 185), disiplin menjadi hal yang mutlak dan harus dilaksanakan dalam organisasi, tanpa adanya dukungan dari karyawan yang memiliki disiplin yang baik, perusahaan akan sulit dalam mencapai target kerja yang diharapkan. Dapat dikatakan bahwa kedisiplinan merupakan kunci dari kemampuan organisasi dalam mencapai target dan tujuan yang ditetapkan.

Dari teori pengaruh para ahli, dapat diberikan kesimpulan bahwa disiplin kerja menjadi sebuah hal yang harus dimiliki oleh karyawan untuk mendukung keberhasilan dan peningkatan kinerja yang lebih baik di perusahaan.

\section{Penelitian Terdahulu}

Kuddy, (2017) dalam penelitiannya mengemukakan bahwa Pengaruh Kepemimpinan, Motivasi Dan Disiplin Kerja Terhadap Kinerja Pegawai Pada Dinas Pertanian Dan Ketahanan Pangan Provinsi Papua. Dimana X1= Kepemimpinan, $\mathrm{X} 2=$ Motivasi, $\mathrm{X} 3=$ Displin Kerja, Y= Kinerja Karyawan

Ginting, (2018) dalam penelitiannya mengemukakan bahwa Pengaruh Disiplin Kerja dan Komunikasi Terhadap Kinerja karyawan Pada PT. Sekar Mulia Abdi Medan. Dimana X1= Disiplin Kerja, X2 $=$ Komunikasi, $Y=$ Kinerja Karyawan.

Bangawati, (2018) dalam penelitiannya mengemukakan bahwa Pengaruh Kepemimpinan, Motivasi Kerja Dan Disiplin Kerja Terhadap Kinerja Guru SMKN 7 Makasar. Dimana X1=
NIAGAWAN Vol 9 No 1 Maret 2020 Kepemimpinan, X2= Motivasi Kerja, X3= Displin Kerja, Y= Kinerja Guru

\section{Kerangka Konseptual}

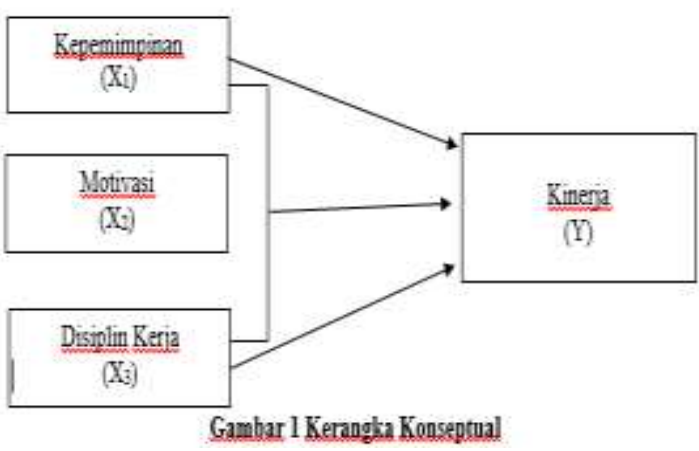

\section{Hipotesis}

Berdasarkan kerangka konseptual yang telah dikemukakan, maka hipotesis penelitian ini dirumuskan sebagai berikut :

1. Kepemimpinan berpengaruh terhadap kinerja karyawan pada PT. PP London Sumatera, Tbk

2. Motivasi berpengaruh terhadap kinerja karyawan pada PT. PP London Sumatera, Tbk

3. Disiplin Kerja berpengaruh terhadap kinerja karyawan pada PT. PP London Sumatera, Tbk

4. Kepemimpinan, Motivasi dan Disiplin Kerja berpengaruh terhadap kinerja karyawan pada PT. PP London Sumatera, Tbk

\section{METODE PENELITIAN}

\section{Tempat dan Waktu Penelitian}

Adapun lokasi dalam penelitian in adalah di PT. PP.London Sumatera, Tbk, Kabupaten Deli Serdang. Penelitian dilakukan pada bulan September sampai Oktober Tahun 2019.

\section{Pendekatan Penelitian}

Pada penelitian ini akan disusun penelitian berdasarkan alur yang telah ditetapkan dan teratur. Menurut Sugiyono (2012:7) penelitian kuantitatif adalah model penelitian dengan 
menggunakan angka-angka sebagai hasil statistik yang akan diuji.

\section{Jenis Penelitian}

Jenis penelitian ini merupakan jenis penelitian deskriptif kuantitatif. Menurut Sujarweni (2015:49), "Penelitian deskriptif adalah penelitian yang dilakukan untuk mengetahui nilai dari masing-masing variabel yang diuji baik satu variabel maupun variabel lainnya tanpa membuat perbandingan dengan variabel yang tidak diteliti”.

\section{Populasi dan Sampel}

\section{Populasi}

Menurut Sugiyono (2013:115) "Populasi adalah keseluruhan dari objek yang akan diteliti”. Adapun yang menjadi populasi penelitian ini adalah seluruh seluruh karyawan PT. PP London Sumatera, Tbk yang berjumlah 142 orang.

Menurut Sugiyono (2013: 116) : "Sampel adalah bagian dari jumlah dan karakteristik yang dimiliki oleh populasi tersebut". Besarnya jumlah sampel dalam Penelitian ini, maka peneliti menggunakan rumus Slovin untuk memperkecil jumlah populasi, hal tersebut dikarenakan keterbatasan waktu, biaya, dan tenaga peneliti, berikut adalah rumus yang digunakan, yaitu :

$$
n=\frac{N}{1+N e^{2}}
$$

Dimana $: \mathrm{n}=$ Jumlah Sampel, $\mathrm{N}=$ Jumlah Populasi, $\alpha^{2}=$ Presisi yang diharapkan 5\%

$$
n=\frac{142}{1+142.0 .05^{2}}, \quad \mathrm{n}=104.79 \quad \text { dibulatkan }
$$

menjadi 105 orang. Teknik pengambilan sampel dalam penelitian ini adalah menggunakan random sampling.

\section{Teknik Pengumpulan Data}

\section{Teknik} NIAGAWAN Vol 9 No 1 Maret 2020 digunakan adalah:

1. Wawancara (Interview)

2. Daftar pertanyaan (Questionare).

3. Studi dokumentasi.

\section{Uji Validitas dan Reliabilitas Instrumen Variabel}

\section{Uji Validitas}

Uji validitas yang dibahas adalah validitas item kuisioner. Menurut Priyatno (2013:19), uji validitas dilakukan untuk mengukur secara cermat suatu item pertanyaan yang akan diukur. Untuk penentuan kelayakan item yang akan diuji, maka dilakukan dengan menilai dan melakukan uji dengan tahap signifikan korelasi 0,05 dan artinya suatu pertanyaan dianggap valid jika memiliki nilai lebih besar dari 0,05 .

Menurut Torang (2013:290), di dalam melakukan pengujian akan dibandingkan antara $r$ hitung dengan $r$ tabel dengan nilai $r$ tabel sebesar $=0,361$ dengan alpha 0,05. Jika $\mathrm{r}$ hitung lebih besar dari $\mathrm{r}$ tabel, maka pertanyaan tersebut dikatakan valid.

\section{Uji Reliabilitas}

Menurut Priyatno (2013:30), pengukuran realibilitas dilakukan untuk mengukur kondisi yang sama dalam waktu yang berbeda dalam melakukan penelitian. Metode uji reliabilitas yang sering digunakan adalah Cronbach's Alpha". Menurut Priyatno (2013:30) pengambilan keputusan untuk uji reliabilitas sebagai berikut:

1. Cronbach's alpha $<0,6=$ reliabilitas buruk.

2. Cronbach's alpha $0,6-0,79=$ reliabilitas diterima.

3. Cronbach's alpha $0,8=$ reliabilitas baik.

\section{Uji Asumsi Klasik}

Uji Normalitas 
Menurut Ghozali (2013:160-164), uji normalitas dilakukan untuk menguji data apakah memiliki distribusi normal seperti yang dijelaskan bahwa uji $\mathrm{F}$ dan uji $\mathrm{t}$ harus memiliki distribusi normal. Uji normalitas harus dipenuhi agar sampel menjadi valid dan bila tidak dipenuhi akan dianggap tidak valid.

\section{Uji Multikolinieritas}

Menurut Ghozali (2013:105),

"Multikolinieritas dapat juga dilihat dari (1) nilai Tolerance dan lawannya (2) variance inflation factor (VIF). Tolerance mengukur variabilitas variabel independen yang terpilih yang tidak dijelaskan oleh variabel independen lainnya

\section{Uji Heteroskedastisitas}

Menurut Ghozali (2013:139), “Uji heteroskedastisitas bertujuan menguji apakah dalam model regresi terjadi ketidaksamaan varians dari residual satu pengamatan ke pengamatan lain.”. Prasyarat yang harus terpenuhi dalam model regresi adalah tidak adanya masalah heteroskedastisitas. Cara pengambilan keputusan adalah dengan melihat grafik Scatterplot dan Uji Glejser.

\section{Uji Hipotesis}

\section{Analisis Linier Berganda}

Pengujian hipotesis menggunakan :

Menurut Sugiyono (2011:277), “Analisis regresi berganda adalah analisis yang digunakan peneliti, bila bermaksud meramalkan bagaimana keadaan (naik turunnya) variabel dependen (kriterium), bila dua atau lebih variabel independen sebagai faktor prediktor dimanipulasi (dinaik turunkan nilainya)". Persamaan linear adalah sebagai berikut :

$$
Y=a+b_{1} X_{1}+b_{2} X_{2}+b_{3} X_{3}+e
$$

\section{Koefisien Determinasi $\left(\mathbf{R}^{2}\right)$}

NIAGAWAN Vol 9 No 1 Maret 2020

Menurut Ghozali (2013:97), koefisien determinasi digunakan untuk mengukur kemampuan variabel dependen mempengaruhi variabel independen. Dengan nilai koefisien determinasi yang kecil, maka kemampuan variabel mempengaruhi cukup rendah, sebaliknya dengan nilai yang besar, maka kemampuan variabel untuk mempengaruhi lebih baik. Nilai yang mendekati satu akan menjelaskan bahwa semua informasi yang dibutuhkan mampu untuk memprediksi variabel dependen.

\section{Pengujian Hipotesis Secara Simultan (Uji F)}

Menurut Ghozali (2013:98), "Uji statistik F pada dasarnya menunjukkan apakah semua variabel bebas yang dimasukkan dalam model mempunyai pengaruh secara simultan terhadap variabel dependen". Dalam penelitian ini nilai $F$ hitung akan dibandingkan dengan nilai $\mathrm{F}$ tabel, pada tingkat signifikan $(\alpha)=5 \%$.

\section{Pengujian Hipotesis Secara Parsial (Uji t)}

Menurut Ghozali (2013:98), “uji t dilakukan untuk menunjukkan pengaruh antara satu variabel dengan variabel lainnya dengan anggapan bahwa variabel lain yang diuji adalah konstan atau nol". Dalam penelitian ini nilai $\mathrm{t}_{\text {hitung }}$ akan dibandingkan dengan nilai $t_{\text {tabel, }}$ pada tingkat signifikan $(\alpha)=5 \%$.

\section{HASIL DAN PEMBAHASAN}

Gambaran Umum PT. PP. London Sumatera,Tbk

PT. PP London Sumatra Indonesia, Tbk (Lonsum) didirikan pada tahun 1906 dengan awal mula sebuah perkebunan tembakau dan kopi di daerah bagian Medan, Sumatera Utara. Dengan diawali dari perkebunan tembakau, kemudian 
perseroan ini berkembang menjadi salah satu perusahaan agribisnis terbesar, memiliki 90,000 hektar kelapa sawit, teh dan kakao yang tersebar di empat pulau besar di Indonesia. Pada awal pendirian, perusahaan melakukan diversifikasi objek bisnis ke kelapa sawit, karet, teh dan kakao. Pada awalnya Lonsum lebih memfokuskan bisnis ke kelapa sawit pada era 1980. Lonsum saat ini memiliki 37 perkebunan sawit inti dan 14 perkebunan plasma di pulau Sumatera, Jawa, Kalimantan dan Sulawesi. Pengelolaan Lonsum dilakukan dengan menerapkan kemajuan penelitian, pengembangan dan keahlian di bidang agro manajemen dengan tenaga kerja yang terampil dan profesional. Lonsum mencakup dari pembibitan, penananaman, panen, pengolahan, pemrosesan dan penjualan produk yang berkaitan dengan kelapa sawit, teh dan kakao. Dalam dunia industri, Lonsum dikenal sebagai produsen bibit kelapa sawit dan kakao yang memiliki kualitas baik. Lonsum melakukan go public pada 1996 dan resmi terdaftar di Bursa Efek Jakarta (saat ini IDX) dan Bursa efek surabaya. Pada Oktober 2007, Indofood Agri Resources menjadi pemegang saham mayoritas Lonsum dengan dibawahi oleh anak usaha Indofood yaitu PT Salim Ivomas Pratama.

\section{Visi dan Misi PT. PP. London Sumatera,Tbk}

Visi PT London PT. PP. London Sumatera, Tbk Menjadi perusahaan agribisnis terkemuka yang berkelanjutan dalam hal tanaman, biaya, lingkungan (3C) yang berbasis penelitian dan pengembangan. Misi PT London PT. PP. London Sumatera,Tbk Menambah nilai bagi Stakeholders di bidang Agribisnis

\section{Analisis Statistik Deskriptif}

Analisis statistik deskriptif menjelaskan jumlah populasi $(\mathrm{N})$, nilai minimum (Minimum), nilai maksimum (Maximum), nilai rata-rata (Mean), dan nilai standar deviasi (Std Deviation) yang diperoleh dari hasil jawaban dan pengolahan data SPSS.

Tabel 2

Analisis Statistik Deskriptif Descriptive Statistics

\begin{tabular}{|l|c|r|r|r|c|}
\hline & $\mathrm{N}$ & $\begin{array}{c}\text { Minimu } \\
\mathrm{m}\end{array}$ & $\begin{array}{c}\text { Maxim } \\
\text { um }\end{array}$ & Mean & $\begin{array}{c}\text { Std. } \\
\text { Deviatio } \\
\mathrm{n}\end{array}$ \\
\hline Kepemimpi & 105 & 12.00 & 29.00 & 18.5810 & 3.69194 \\
nan & 105 & 11.00 & 29.00 & 21.2571 & 3.58155 \\
Motivasi & 105 & 11.00 & 28.00 & 21.4952 & 3.82835 \\
Disiplin & 105 & 11.00 & 27.00 & 20.2190 & 3.13780 \\
Kinerja & 105 & & & & \\
Valid N & & & & \\
(listwise) & 105 & & \\
\hline
\end{tabular}

Sumber : Hasil Penelitian, 2019 (Data diolah)

Dari hasil Tabel 3 dapat diketahui nilai dari analisis statistik deskriptif variabel kepemimpinan dengan sampel sebanyak 105 responden memiliki rata-rata sebesar 18,5810 dengan nilai minimum 12 dan nilai maksimum 29 dengan standard deviasi 3,69194.

Nilai dari analisis statistik deskriptif variabel motivasi dengan sampel sebanyak 105 responden memiliki rata-rata sebesar 21,2571 dengan nilai minimum 11 dan nilai maksimum 29 dengan standard deviasi 3,58155.

Nilai dari analisis statistik deskriptif variabel variabel disiplin dengan sampel sebanyak 105 responden memiliki rata-rata sebesar 21,4952 dengan nilai minimum 11 dan nilai maksimum 28 satuan dengan standard deviasi 3,82835.

Nilai dari analisis statistik deskriptif variabel variabel kinerja dengan sampel sebanyak 105 responden memiliki rata-rata sebesar 20,2190 dengan nilai minimum 11 dan nilai maksimum 27 satuan dengan standard deviasi 3,13780. 


\section{Hasil Uji Asumsi Klasik}

\section{Uji Normalitas}

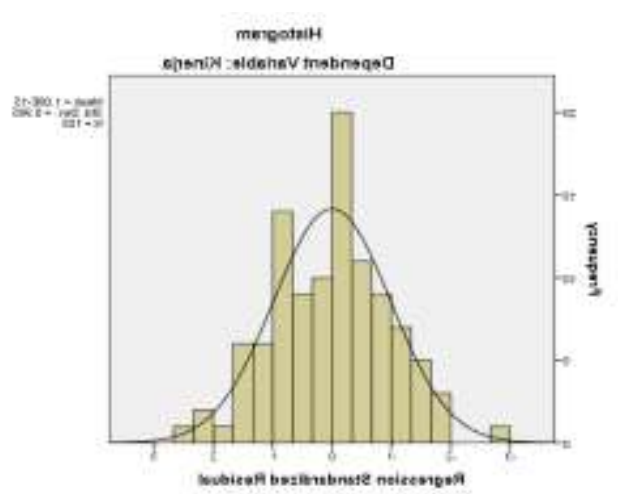

Gambar 2 Grafik Histogram

Sumber : Hasil Penelitian, 2019 (Data diolah)

Grafik histogram pada Gambar 2 menunjukkan grafik histogram membentuk kurva $\mathrm{U}$ dan berada di tengah sehingga dapat dinyatakan layak dalam berasumsi normalitas.

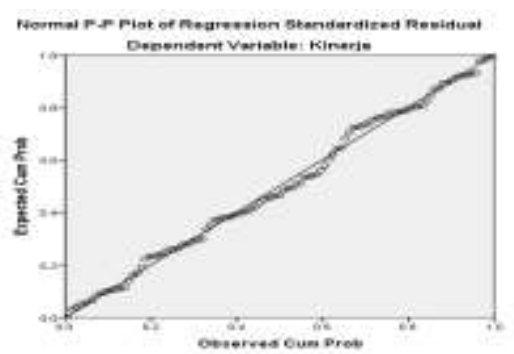

\section{Gambar 3. Uji Normalitas P-P Plot}

Sumber : Hasil Penelitian, 2019 (Data diolah)

Grafik Normalitas P-P Plot pada

Gambar.3 diatas, data menyebar dan mengikuti pola garis diagonal, data menyebar di sekitar garis dan mendekati garis diagonal, maka dapat diberikan penilaian bahwa data layak dan memenuhi dalam kriteria normalitas yang telah ditetapkan.
Uji Normalitas One Sample Kolmogorov

Smirnov

One-Sample Kolmogorov-Smirnov Test

\begin{tabular}{|ll|r|}
\hline & & $\begin{array}{c}\text { Unstandardized } \\
\text { Residual }\end{array}$ \\
\hline $\mathrm{N}$ & Mean & 105 \\
Normal & .0000000 \\
Parameters & Stb & Std. Deviation \\
Most Extreme & Absolute & 2.63859106 \\
Differences & Positive & .059 \\
& Negative & .045 \\
Test Statistic & &. .059 \\
Asymp. Sig. (2-tailed) & .059 \\
\hline
\end{tabular}

a. Test distribution is Normal.

b. Calculated from data.

c. Lilliefors Significance Correction.

d. This is a lower bound of the true significance.

Sumber : Hasil Penelitian, 2019 (Data diolah)

Hasil uji normalitas dapat terlihat nilai signifikan sebesar 0,200 >0,05 dan menunjukkan bahwa data memenuhi asumsi normalitas data.

\section{Uji Multikolinearitas}

\section{Tabel 5}

Uji Multikolinearitas

Coefficients $^{\mathrm{a}}$

\begin{tabular}{|ll|r|c|}
\hline \multirow{2}{*}{ Model } & \multicolumn{2}{|c|}{ Collinearity Statistics } \\
\cline { 3 - 4 } & & Tolerance & \multicolumn{1}{c|}{ VIF } \\
\hline 1 & (Constant) & & \\
& Kepemimpinan & .864 & 1.158 \\
& Motivasi & .843 & 1.186 \\
& Disiplin & .970 & 1.031 \\
\hline
\end{tabular}

a. Dependent Variable: Kinerja

Sumber : Hasil Penelitian, 2019 (Data diolah)

Nilai tolerance untuk variabel kepemimpinan, motivasi dan disiplin berada diatas 0,10 sedangkan nilai VIF variabel kepemimpinan, motivasi dan disiplin berada dibawah 10. Dengan demikian pada uji multikolinearitas tidak terjadi korelasi antar variabel independen.

\section{Uji Heteroskedastisitas}




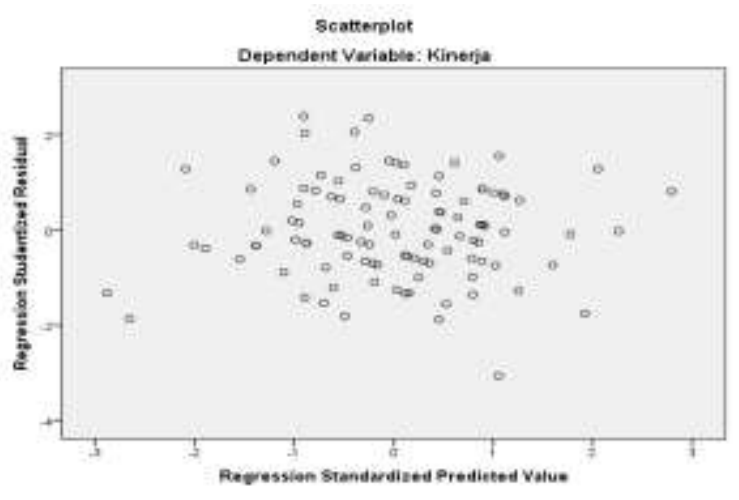

Gambar 4 Uji Heteroskedastisitas Grafik

\section{Scatterplot}

Sumber : Hasil Penelitian, 2019 (Data diolah)

Dari grafik scatterplot terlihat bahwa titik-titik di garis menyebar tidak membentuk pola yang wajar (acak), maka dapat dinyatakan bahwa data memenuhi asumsi klasik dan tidak terjadi gejala heterokedastisitas sesuai yang diharapkan.

$$
\text { Pendeteksian ada tidaknya }
$$

heteroskedastisitas bisa juga dilakukan dengan menggunakan metode Glejser Test. Jika nilai signifikasi antara variabel independen dengan residual lebih dari 0,05 maka tidak terjadi heterokedastisitas

Tabel 6 Uji Glejser Coefficients $^{a}$

\begin{tabular}{|c|c|c|c|c|}
\hline \multirow[b]{2}{*}{ Model } & \multicolumn{2}{|c|}{$\begin{array}{l}\text { Unstandardized } \\
\text { Coefficients }\end{array}$} & \multirow[b]{2}{*}{$\mathrm{T}$} & \multirow[b]{2}{*}{ Sig. } \\
\hline & B & $\begin{array}{l}\text { Std. } \\
\text { Error }\end{array}$ & & \\
\hline 1 (Constant) & $\begin{array}{r}2.876 \mathrm{E}- \\
15\end{array}$ & 2.145 & .000 & 1.000 \\
\hline $\begin{array}{l}\text { Kepemimpin } \\
\text { an }\end{array}$ & .000 & .077 & .000 & 1.000 \\
\hline Motivasi & .000 & .080 & .000 & 1.000 \\
\hline Disiplin & .000 & .070 & .000 & 1.000 \\
\hline
\end{tabular}

a. Dependent Variable: Unstandardized Residual Sumber : Hasil Penelitian, 2019 (Data diolah)
NIAGAWAN Vol 9 No 1 Maret 2020

Hasil uji glejser Pada Tabel 6 diatas menunjukkan nilai signifikan dari kepemimpinan $1,000>0,05$, motivasi $1,000>0,05$ dan disiplin $1,000>0,05$ dengan demikian dari hasil uji Glejser dapat dikatakan tidak terjadi masalah heteroskedastisitas.

\section{Hasil Analisis Data Penelitian}

\section{Model Penelitian}

Tabel 7 Analisis Linier Berganda

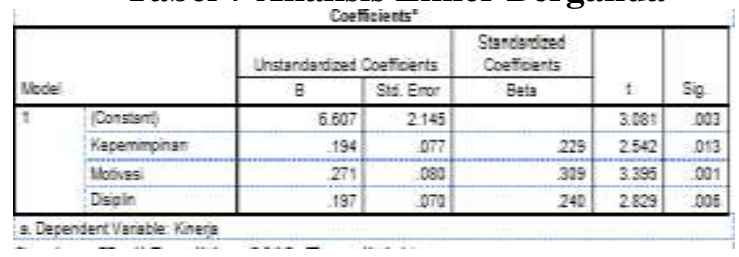

Sumber : Hasil Penelitian, 2019 (Data diolah)

Kinerja Karyawan $=\mathbf{6 , 6 0 7}+\mathbf{0 , 1 9 4}$

\section{Kepemimpinan + 0,271 Motivasi + 0,197}

\section{Disiplin}

Pemahaman dari tabel di atas adalah :

1. Dengan nilai konstan 6,607 menyatakan bahwa jika kepemimpinan, motivasi dan disiplin tidak ada atau konstan maka kinerja karyawan sebesar 6,607 satuan.

2. Variabel kepemimpinan sebesar 0,194 dan bernilai positif, hal ini menyatakan bahwa setiap kenaikan kepemimpinan 1 satuan akan meningkatkan kinerja karyawan sebesar 0,194 satuan dengan anggapan variabel lainnya tetap.

3. Variabel sebesar 0,271 dan bernilai positif, hal ini menyatakan bahwa setiap kenaikan motivasi 1 satuan akan menyebabkan kenaikan kinerja karyawan sebesar 0,271 satuan dengan anggapan variabel lainnya tetap.

4. Variabel disiplin sebesar 0,197 dan bernilai positif, hal ini menyatakan bahwa setiap kenaikan disiplin 1 satuan akan menyebabkan 
kenaikan kinerja karyawan sebesar 0,197 satuan dengan anggapan variabel lainnya tetap.

\section{Koefisien Determinasi Hipotesis}

Tabel 8 Uji Koefisien Determinasi Model Summaryb

\begin{tabular}{|l|c|c|r|c|}
\hline Model & $\mathrm{R}$ & $\begin{array}{c}\mathrm{R} \\
\text { Square }\end{array}$ & $\begin{array}{c}\text { Adjusted } \\
\text { R Square }\end{array}$ & $\begin{array}{c}\text { Std. Error of the } \\
\text { Estimate }\end{array}$ \\
\hline 1 & $.541^{\mathrm{a}}$ & .293 & .272 & 2.67749 \\
\hline
\end{tabular}

a. Predictors: (Constant), Disiplin, Kepemimpinan, Motivasi b. Dependent Variable: Kinerja

Sumber : Hasil Penelitian, 2019 (Data diolah)

Hasil Uji Koefisien Determinasi diperoleh nilai $R$ square sebesar 0,272 hal ini berarti $27,2 \%$ dari variasi variabel dependen kinerja karyawan yang dapat dijelaskan oleh variasi variabel independen kepemimpinan, motivasi dan disiplin sisanya sebesar 72,8\% (100\% - 27,2\%) dijelaskan oleh variabel lain yang tidak diteliti pada penelitian ini, seperti budaya organisasi, kepemimpinan dan lain-lain.

\section{Pengujian Hipotesis Secara Simultan}

Tabel 9 Uji F

ANOVA $^{\mathrm{a}}$

\begin{tabular}{|l|r|r|r|r|r|}
\hline Model & \multicolumn{1}{|c|}{$\begin{array}{c}\text { Sum of } \\
\text { Squares }\end{array}$} & \multicolumn{1}{c|}{ df } & $\begin{array}{c}\text { Mean } \\
\text { Square }\end{array}$ & F & Sig. \\
\hline $1 \begin{array}{l}\text { Regres } \\
\text { sion } \\
\text { Residu } \\
\text { al } \\
\text { Total }\end{array}$ & 299.897 & 3 & 99.966 & 13.944 & $.000^{\mathrm{b}}$ \\
\hline
\end{tabular}

a. Dependent Variable: Kinerja

b. Predictors: (Constant), Disiplin, Kepemimpinan, Motivasi Sumber : Hasil Penelitian, 2019 (Data diolah)

Uji signifikansi simultan / bersama-sama (uji statistik F) menghasilkan nilai $F$ hitung sebesar 13,944 . Pada derajat bebas $1\left(\mathrm{df}_{1}\right)=\mathrm{k}-1$
NIAGAWAN Vol 9 No 1 Maret 2020 $=4-1=3$, dan derajat bebas $2\left(\mathrm{df}_{2}\right)=\mathrm{n}-\mathrm{k}=105-$ $4=101$, dimana $\mathrm{n}=$ jumlah sampel, $\mathrm{k}=$ jumlah variabel, maka nilai $\mathrm{F}$ tabel pada taraf kepercayaan signifikansi 0,05 adalah 2,69 dengan demikian dari hasil perhitungan SPSS diperoleh nilai $\mathrm{F}_{\text {hitung }}=13,944>\mathrm{F}_{\text {tabel }}=2,69$ dengan tingkat signifikansi 0,000 karena $\mathrm{F}_{\text {hitung }}=13,944$ $>\mathrm{F}_{\text {tabel }}=2,69$ dan probabilitas signifikansi 0,000 $<0,05$, maka $\mathrm{H}_{4}$ diterima artinya kepemimpinan, motivasi dan disiplin secara simultan berpengaruh positif dan signifikan terhadap kinerja karyawan

\section{Pengujian Hipotesis Secara Parsial}

Tabel 10 Uji t

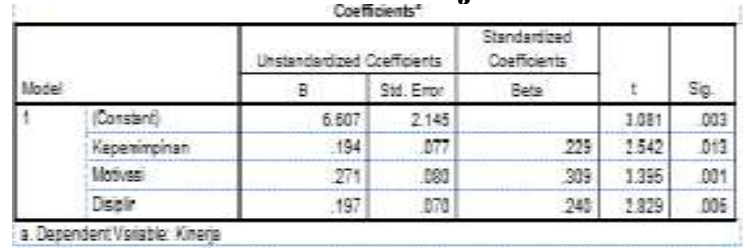

Sumber : Hasil Penelitian, 2019 (Data diolah)

Nilai t tabel untuk probabilitas 0,05 pada derajat bebas $(\mathrm{df})=101$ adalah sebesar 1.98373 .

1. Hasil perhitungan uji $\mathrm{t}$ secara parsial diperoleh nilai t hitung kepemimpinan sebesar 2,542 dengan nilai signifikan sebesar 0,013 . Nilai $t$ hitung $>t$ tabel atau $2,542>1,983$, dan signifikansi $<0,05$ maka $\mathrm{H}_{1}$ diterima artinya kepemimpinan berpengaruh positif dan signifikan terhadap kinerja karyawan di PT PP London Sumatra, Tbk.

2. Hasil perhitungan uji $\mathrm{t}$ secara parsial diperoleh nilai t hitung motivasi sebesar 3,395 dengan nilai signifikan sebesar 0,001. Nilai t hitung $>\mathrm{t}$ tabel atau 3,395 $>1,983$, dan signifikansi < 0,05 maka $\mathrm{H}_{2}$ diterima artinya motivasi berpengaruh 
positif dan signifikan terhadap kinerja karyawan di PT PP London Sumatra, Tbk.

3. Hasil perhitungan uji $\mathrm{t}$ secara parsial diperoleh nilai t hitung disiplin sebesar 2,829 dengan nilai signifikan sebesar 0,006 . Nilai t hitung $>\mathrm{t}$ tabel atau 2,829 $>1,983$, dan signifikansi $<0,05{\text { maka } \mathrm{H}_{3}}$ diterima artinya disiplin berpengaruh positif dan signifikan terhadap kinerja karyawan di PT PP London Sumatra, Tbk.

\section{KESIMPULAN}

Dari hasil penelitian dan pembahasan, maka dapat ditarik kesimpulan sebagai berikut:

Variabel kepemimpinan secara parsial berpengaruh positif dan signifikan terhadap kinerja karyawan pada PT. PP London Sumatera, Tbk.

Variabel motivasi secara parsial berpengaruh positif dan signifikan terhadap kinerja karyawan pada PT. PP London Sumatera, Tbk.

Vvariabel disiplin secara parsial berpengaruh positif dan signifikan terhadap kinerja karyawan pada PT. PP London Sumatera, Tbk

Variabel kepemimpinan, motivasi dan disiplin secara simultan berpengaruh positif dan signifikan terhadap kinerja karyawan pada PT. PP London Sumatera, Tbk dengan nilai koefisien determinasi sebesar $27,2 \%$

\section{SARAN}

Berdasarkan kesimpulan sebelumnya, maka peneliti menyarankan sebagai berikut:
NIAGAWAN Vol 9 No 1 Maret 2020

PT. PP London Sumatera Utara,Tbk pada permasalahan kepemimpinan dapat diberikan saran untuk lebih memberikan kebebasan kepada karyawan dalam menyelesaikan masalah dan melakukan pengambilan keputusan. Selain itu karyawan diberikan kebebasan untuk berpikir dan memiliki inisiatif sendiri untuk melaksanakan semua tugas yang diberikan. Pada permasalahan motivasi, pemberian bonus masih perlu disesuaikan oleh perusahaan berdasarkan kinerja. Dalam hal ini perusahaan perlu memberikan kenaikan yang sesuai dengan kinerja karyawan dan memiliki angka yang tetap pada setiap tahunnya. Pada permasalahan disiplin, pimpinan di perusahaan perlu memperketat pemberian izin dan melakukan kontrol kepada karyawan yang dianggap sengaja dalam izin bekerja untuk diberikan sanksi tegas sesuai dengan jumlah kesalahan yang dibuat.

\section{REFERENSI}

Bangun, Wilson. 2012. Manajemen Sumber Daya Manusia. Jakarta: Erlangga.

Bungawati. 2018. Pengaruh Kepemimpinan, Motivasi Kerja Dan Disiplin Kerja Terhadap Kinerja Guru SMKN 7 Makassar. Jurnal Unismuh Vol 10 No 2.

Sari,YantiKomala.2014.Pengaruh Kepemimpinan, Motivasi dan Disiplin Kerja Terhadap Kinerja Karyawan Pada PT. Patra Komala di Dumai. Jurnal Tepak Manajemen Bisnis. Vol. VI No. 2.

Nisyak, Ila Rohmatun., dan Trijonowati. 2016. Pengaruh Gaya Kepemimpinan, Motivasi dan Disiplin Kerja Terhadap Kinerja Karyawan. Jurnal Ilmu dan Riset Manajemen : Volume 5, NO. 4, STIESIA 
Suleman, Suhaemi dan Ruliaty. 2016.

Pengaruh Gaya Kepemimpinan Kepala Sekolah, Budaya Sekolah, dan Disiplin Guru Terhadap Kinerja Guru pada Sekolah Menengah Kejuruan (SMK) Negeri I Jeneponto. Jurnal Competitiveness ISSN:1978-3035. Vol. 10, Nomor 2. JuliDesember,2016.http://journal.unismuh.a c.id/index.php/competitiveness.

Notoadmodjo, Soekidjo 2015. Pengembangan Sumber Daya Manusia. Cetakan ke-2, Jakarta : PT. Rineka Cipta.

Susitianingrum, Noeria., Djoko, Handoyo., \& Reni Shinta Dewi. 2015.

Pengaruh Lingkungan Kerja, Motivasi Kerja dan Disiplin Kerja Terhadap Kinerja Karyawan Bagian Produksi PT. Njonja Meneer Semarang. Diponegoro Journal of Social and Political of Science.Hal.1-11. http://ejournals1.undip.ac.id/index.php/

Endah Susetyo Indriyati. 2017. Pengaruh gaya kepemimpinan, motivasi dan disiplin kerja terhadap kinerja karyawan dengan pemahaman etika kerja islami. Jurnal Upajiwa Dewantara Vol. 1 No. 2

Noor, Juliansyah. 2013. Penelitian IImu Manajemen. Cetakan Kesatu, Jakarta : Kencana Media Group.

Suyono, Wahyu Galih Pramudito. 2014. Pengaruh Motivasi, Kemampuan dan Disiplin Terhadap Kinerja Karyawan (Studi pada Radio Republik Indonesia Semarang). Jurnal Fakultas Ekonomi dan Bisnis Universitas Dian Nuswantoro

Tampi, Bryan Johannes. 2014. Pengaruh Gaya Kepemimpinan dan Motivasi Terrhadap Kinerja Karyawan pada PT. Bank Negara Indonesia, Tbk (Regional Sales Manado). Journal "Acta Diurna" Volume III. No.4.

Rivai, Veithzal dan Ella Jauvani Sagala. 2011. Manajemen Sumber Daya Manusia untuk Perusahaan, Cetakan Keempat, Edisi-2. Jakarta: Rajawali Pers.

Yazid, Musnadi dan Chan, 2013. Pengaruh Gaya Kepemimpinan, Budaya Organisasi dan Motivasi Kerja Terhadap Prestasi Pegawai
NIAGAWAN Vol 9 No 1 Maret 2020

Administrasi serta Dampaknya pada Kinerjapoliteknik Negeri Lhoseumawe, Aceh. Jurnal Manajemen Pascasarjana Universitas Syiah Kuala. ISSN 23020199. pp. 78- 87.

Suranto dan Lestari, Etty Puji. 2014. Pengaruh Motivasi, Gaya Kepemimpinan dan Disiplin Kerja Terhadap Kinerja Pegawai pada KPPN Percontohan Jambi, Bangko dan Muara Bungo. Jurnal Organisasi dan Manajemen, Volume 10, Nomor 2, September 2014,148-160.

Sugiyono. 2011. Metode Penelitian Kuantitatif Kualitatif dan $R \& \boldsymbol{D}$. Bandung: Alfabeta

Harlie, M. 2013. Pengaruh Disiplin Kerja, Motivasi dan Pengembangan Karier terhadap Kinerja Pegawai Negeri Sipil pada Pemerintah Kabupaten Tabalong di Tanjung Kalimantan Selatan. Jurnal Aplikasi Manajemen. Vol. 10 (4) Kalimantan Selatan.

Darmawan, Didit. 2013. Prinsip-prinsip Perilaku Organisasi. Cetakan Pertama, Surabaya: Pena Semesta.

Fahmi, Irham, 2013. Manajemen Kepemimpinan, Cetakan Kesatu, Penerbit ALFABETA, Bandung.

Feriyanto, Andri, Shyta, Endang Triana. 2015. Pengantar Manajemen (3 in 1) Untuk Mahasiswa dan Umum, Cetakan Pertama. Yogyakarta: Mediatera.

Ghozali, Imam. 2013. Aplikasi Analisis Multivariat dengan Program SPSS 21, Cetakan Ketujuh. Semarang: Badan Penerbit Universitas Diponegoro.

Ginting, Nurmaidah Br. 2018. Pengaruh Disiplin Kerja dan Komunikasi Terhadap Kinerja Karyawan pada PT Sekar Mulia Abadi Medan. Asian Journal of Innovation and Entrepreneurship. Volume 3 No 2.

Hartatik, Indah Puji. 2014. Buku Praktis Mengembangkan SDM. Jakarta: Laksana. 
Hasibuan, H. Malayu. 2012. Manajemen Sumber

Daya Manusia. Edisi Revisi, Jakarta: PT. Bumi Aksara.

Kuddy, Andarias. 2017.Pengaruh Kepemimpinan, Motivasi, dan Disiplin Kerja Terhadap Kinerja Pegawai Pada Dinas Pertanian dan Ketahanan Pangan Provinsi Papua. Jurnal Manajemen \& Bisnis. Volume 1, No 2.

Moeheriono. 2014. Pengukuran Kinerja Berbasis Kompetensi. Edisi Revisi. Jakarta: PT. RajaGrafindo Persada.

.Priansa, Donni Junni. 2016. Perencanaan dan Pengembangan SDM. Cetakan Kedua : Bandung, Penerbit Alfabeta.

Sinambela, Lijan Poltak. 2016. Manajemen Sumber Daya Manusia Membangun Tim Kerja yang Solid Untuk Meningkatkan Kinerja. Jakarta : Bumi Aksara.

.Sujarweni, Wiratna. 2015. SPSS Untuk Penelitian. Yogyakarta : Pustaka Baru Press

Sutrisno, H. Eddy. 2012. Manajemen Sumber Daya Manusia. Jakarta: Kencana.

Torang, Syamsir. 2013. Organisasi Dan Manajemen. Cetakan Kesatu, Bandung: Penerbit Alfabeta,

Wibowo.2014. Manajemen Kinerja. Cetakan Keempat. Jakarta: Rajagrafindo Persada

Priyatno, Duwi. 2013. Mandiri Belajar Analisis Data Dengan SPSS, Cetakan Pertama. Yogyakarta: Mediakom. 